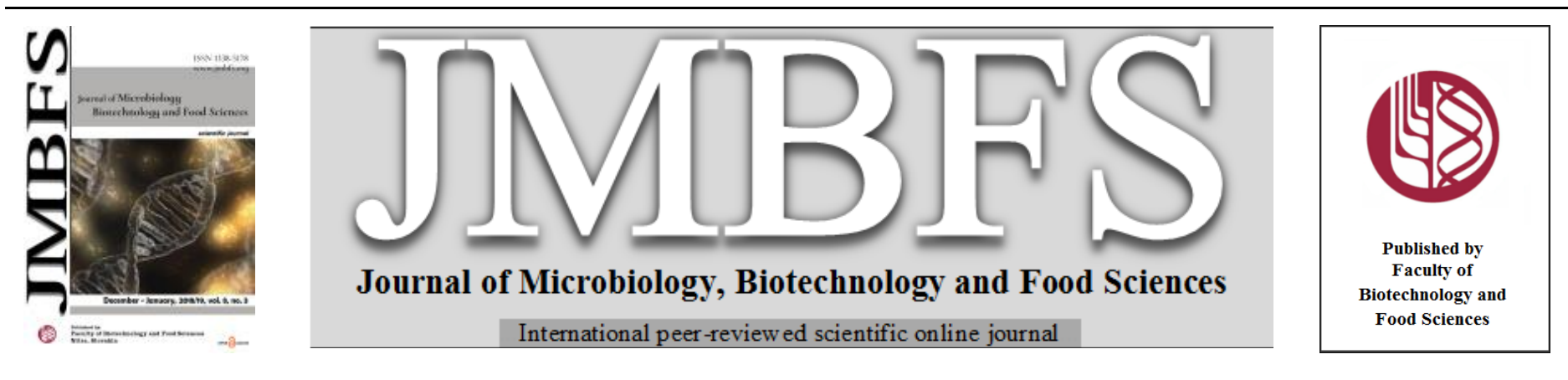

\title{
ZINC AFFECTS RABBIT SPERMATOZOA IN VITRO: EFFECTS ON MOTILITY AND VIABILITY
}

\author{
Marko Halo Jr. ${ }^{1 *}$, Filip Tirpák ${ }^{1}$, Adam Daňo ${ }^{1}$, Katarína Zbyňovskál, Anton Kováčik ${ }^{1}$, Lubomír Ondruška ${ }^{2}$, Agnieszka Greñ $^{3}$, Norbert $^{\prime}$ \\ Lukáč ${ }^{1}$, Peter Massányi ${ }^{1}$
}

Address(es): Ing. Marko Halo,

${ }^{1}$ Slovak University of Agriculture in Nitra, Faculty of Biotechnology and Food Sciences, Department of Animal Physiology, Tr. A. Hlinku 2, 949 76, Nitra, Slovak Republic.

${ }^{2}$ National Agricultural and Food Centre, Research Institute for Animal Production Nitra, Institute of Small Farm Animals, Hlohovecká 2, 95141 Lužianky, Slovak Republic.

${ }^{3}$ Institute of Biology, Pedagogical University of Cracow ul. Podchorązych 2, 30-084 Krakow, Poland.

*Corresponding author: markohalo@yahoo.com

doi: 10.15414/jmbfs.2018-19.8.3.901-904

\section{ARTICLE INFO}

Received 26. 6. 2018

Revised 25. 9. 2018

Accepted 25. 9. 2018

Published 1. 12. 2018

Regular article open $\bigodot_{\text {ACCESS }}$

\begin{abstract}
Zinc is an essential trace element, which plays important roles in different biological activities. The aim of this study was to evaluate the effect of zinc on rabbit spermatozoa during in vitro conditions. Fresh semen was obtained from 8 sexually mature New Zealand White rabbits, which were bred at National Agricultural and Food Centre in Lužianky. Experimental groups were prepared by diluting the semen with two forms of zinc $\left(\mathrm{ZnCl}_{2}, \mathrm{ZnSO}_{4} .7 \mathrm{H}_{2} \mathrm{O}\right)$ in five different concentration: $\mathrm{ZA}$, ZA1 (4.883 mg Zn. $\left.\mathrm{l}^{-1}\right), \mathrm{ZB}, \mathrm{ZB} 1$ (9.766 mg Zn..$\left.^{-1}\right)$, ZC, ZC1 (19.531 mg Zn..$\left.^{-1}\right)$, ZD, ZD1 (39.063 mg Zn..$\left.^{-1}\right)$, ZE, ZE1 (78.125 mg Zn..$\left.^{-1}\right)$. Experimental samples were compared against control groups (ZK, ZK1). Semen was evaluated using the Computer Assisted Semen Analysis (CASA) at time intervals 0, 60, 120 and 180 minutes after incubation at $39^{\circ} \mathrm{C}$. MTT test was used for determination of cell viability. Results of monitored motility parameters (motility, progressive motility and velocity curved line) showed decreasing trend in experimental samples. Significantly lower values of motility were observed in sample ZE, where percentage of motility decreased to $9.18 \pm 1.34 \%$ and after 180 minutes of incubation. Evaluation of spermatozoa velocity curved line detected significant $(\mathrm{P}<0.001)$ decrease at time intervals 120 and 180 minutes in samples with the highest concentration (ZE) of zinc. Measurement observed results with significant counteractive effect on viability in samples ZA, ZB, ZC1, ZD, ZD1 $(\mathrm{P}<0.05)$ and ZB1, ZC, ZE, ZE1 ( $<<0.01)$ after 180 minutes of incubation. Detected data confirm negative effect of zinc in each concentration on spermatozoa motility parameters and viability. Supplemented zinc in form $\mathrm{ZnCl}_{2}$ to rabbit semen had higher negative impact on rabbit spermatozoa motility and viability parameters than zinc in form $\mathrm{ZnSO}^{4} .7 \mathrm{H}_{2} \mathrm{O}$.
\end{abstract}

Keywords: zinc, rabbit, CASA, MTT, spermatozoa

\section{INTRODUCTION}

Farmers effort to make rabbit production more profitable was in recent years reached mainly by the use of artificial insemination (AI) (Castellini, 2007). The successful insemination requires fully functional spermatozoa with a normal membrane status diluted in extender rich in nourishing and beneficial substances (Fik, 2018; Lukac et al., 2010). Measurement of sperm motility is important tool to determine the potential for successful production of rabbit offspring and monitor the male reproductive performance (Kime et al., 1996; Slanina $\boldsymbol{e t}$ al., 2014).

Zinc is an essential trace element, which plays important roles in different biological processes (Yamaguchi et at., 2009). Its multifaceted role is known in spermatogenesis, testes development, sperm physiologic functions and also has effect on sperm motility (Colagar et al., 2009). Zinc deficiency results in gonadal dysfunction on histological level, however its content is varying throughout the life of the individual. Juvenile testes contain the lowest amount of zinc with increasing trend during puberty. Zinc along with calcium and magnesium can decrease or increase progressive motility with the concentration being the deciding factor (Bedwal and Bahuguna, 1994). Zinc is highly present in prostatic fluid which therefore maintain ideal environment for spermatozoa until the fertilization (Riffo et al., 1992). Furthermore zinc has also antioxidant activity and may decrease the production of reactive oxygen species (Kendall $\boldsymbol{e}$ al., 2000; Valko et al., 2005). The function of zinc is also to be a co-factor for most enzymatic reactions (Kasperczyk et al., 2015). Kerns et al.(2018) recently reported that zinc ions $\left(\mathrm{Zn}^{2+}\right)$ take part in mammalian sperm capacitation. Reduced zinc content in seminal plasma can impair antioxidant defence, however increased zinc content has positive effect on motility and spermatozoa production (Nenkova et al., 2017). Sufficient zinc content in male body support production of testosterone (Favier, 1992). Toxic effect of different toxic elements may be diminished by zinc presence (Massányi et al., 2003) therefore its supplementation is recommended with positive outcome in spermatozoa motility and concentration (Narasimhaiah $\boldsymbol{e t}$ al., 2017). Comparatively little attention has been drawn towards the toxic properties of zinc originated from industrial fume or environmental pollution (Fosmire, 1990). Further zinc toxicity may come from food and beverages contaminated with zinc from galvanized containers (Duncan et al., 1992).

The aim of this study was to evaluate and compare the effect of different forms and concentrations of zinc on rabbit spermatozoa motility and viability parameters during in vitro incubation.

\section{MATERIAL AND METHODS}

\section{Semen collection and processing}

Fresh semen was obtained from 8 sexually mature New Zealand White rabbits, which were bred at National Agricultural and Food Centre in Lužianky. Semen collection was realised by the use of pre-warmed artificial vagina after sexual stimulation by a rabbit doe. Consequently, semen was stored at $37^{\circ} \mathrm{C}$ during transport. Further in lab, aliquots of 8 ejaculates used as controls (ZK, ZK1) were diluted with physiological solution $(\mathrm{NaCl} 0.9 \%$ Braun, B. Braun Melsungen AG, Germany) in ratio 1:7. Experimental samples were prepared according to the same dilution rate, using two forms of zinc $\left(\mathrm{ZnCl}_{2}, \mathrm{ZnSO}_{4} .7 \mathrm{H}_{2} \mathrm{O}\right)$ in five concentrations (Table 1, Table 2) dissolved in the physiological solution. Solutions of zinc were prepared in advance to ensure the proper dissolution of zinc. 
Table 1 Concentration of zinc $\left(\mathrm{ZnCl}_{2}\right)$ used in this study

\begin{tabular}{ccc}
\hline Sample & Concentration of $\mathrm{Zn}\left(\mathrm{mg} . \mathrm{l}^{-1}\right)$ & $\mathrm{ZnCl}_{2}\left(\mathrm{mg} .50 \mathrm{ml}^{-1}\right)$ \\
\hline ZK & 0 & 0 \\
ZA & 4.883 & 0.244 \\
ZB & 9.766 & 0.488 \\
ZC & 19.531 & 0.977 \\
ZD & 39.063 & 1.953 \\
ZE & 78.125 & 3.906 \\
\hline
\end{tabular}

Table 2 Concentration of zinc $\left(\mathrm{ZnSO}_{4} \cdot 7 \mathrm{H}_{2} \mathrm{O}\right)$ used in this study

\begin{tabular}{ccc}
\hline Sample & Concentration of $\mathrm{Zn}\left(\mathrm{mg} . .^{-1}\right)$ & $\mathrm{ZnSO}_{4} .7 \mathrm{H}_{2} \mathrm{O}\left(\mathrm{mg} .50 \mathrm{ml}^{-1}\right)$ \\
\hline $\mathrm{ZK} 1$ & 0 & 0 \\
$\mathrm{ZA} 1$ & 4.883 & 0.373 \\
$\mathrm{ZB} 1$ & 9.766 & 0.747 \\
$\mathrm{ZC} 1$ & 19.531 & 1.494 \\
$\mathrm{ZD} 1$ & 39.063 & 2.987 \\
$\mathrm{ZE} 1$ & 78.125 & 5.975 \\
\hline
\end{tabular}

\section{Motility analyses}

Semen was evaluated using the Computer assisted semen analysis (CASA) method with SpermVision software (Minitube, Tiefenbach, Germany) and the microscope Olympus BX 51 (Olympus, Japan). Each sample was placed into Makler counting chamber (10 $\mu \mathrm{m}$, Sefi-Medical Instruments, Germany) Analyses were realised at four different time periods $(0,60,120,180$ minutes) Samples were stored in incubator at $39^{\circ} \mathrm{C}$ during the whole experiment. In each sample following parameters were evaluated: MOT (motility), PRO (progressive motility), VCL (velocity curved line) (Tirpák et al., 2017; Halo Jr. et al., 2018).

\section{Assessment of mitochondrial toxicity}

The viability of the spermatozoa exposed to both forms of zinc was assessed using the mitochondrial toxicity test (MTT). This colorimetric assay measures the conversion of 3-(4,5-dimetylthiazol-2-yl)-2,5-diphenyltetrazolium bromide (Sigma-Aldrich, St. Louis, USA) to purple formazan particles by mitochondrial succinate dehydrogenase of intact mitochondria of living cells. Optimal density was determined spectrophotometrically at a wavelength of 570 against $620 \mathrm{~nm}$ as reference by a microplate ELISA reader (Multiskan FC, ThermoFisher Scientific, Finland). The data were expressed as percentage against the control which was recalculated to 100\% (Jambor et al., 2017).

\section{Statistical analysis}

All data were analysed by the Statistical Analyses System (SAS 9.2. using of application Enterprise guide 5.1). Means of control and experimental groups (\%, $\left.\mu \mathrm{m} . \mathrm{s}^{-1}\right)$ were analysed by one-way factor analyses applying the Tukey's test. Al statistical tests were carried out at levels of significance at $\mathrm{P}<0.05, \mathrm{P}<0.01$ and $\mathrm{P}<0.001$ and results were interpreted as means and expressed with SD.

\section{RESULTS AND DISCUSSION}

Spermatozoa motility analysis at time intervals $0(79.67 \pm 9.18 \%)$ and $60 \mathrm{~min}$ $(81.27 \pm 4.11 \%)$ showed approximately the same percentage of motility compared to control groups. Motility in experimental groups (ZA, ZB, ZC, ZD, ZE) with addition of zinc $\left(\mathrm{ZnCl}_{2}\right)$ was decreased compared to control group. Significantly decreased motility was found in sample ZE at Time $60(\mathrm{P}<0.01), 120$ and 180 $(\mathrm{P}<0.001)$. Also significant drop-off was measured at Time 180 in samples ZD $(\mathrm{P}<0.001)$ and $\mathrm{ZB}(\mathrm{P}<0.01)$. Same negative effect on motility was found in samples (ZA1, ZB1, ZC1, ZD1, ZE1) with addition of zinc $\left(\mathrm{ZnSO}_{4} .7 \mathrm{H}_{2} \mathrm{O}\right)$ except $Z A$ at interval 120 minutes, where motility was moderately increased against control group. Significantly lower values were observed in sample ZE1 at interval 120 min $(\mathrm{P}<0.05)$ and in 180 minutes $(\mathrm{P}<0.001)$. Rapid lower values of motility were observed in sample with the highest concentration of zinc (ZE), where the percentage of motility decreased to $9.18 \pm 1.34 \%$ (Figure 1).

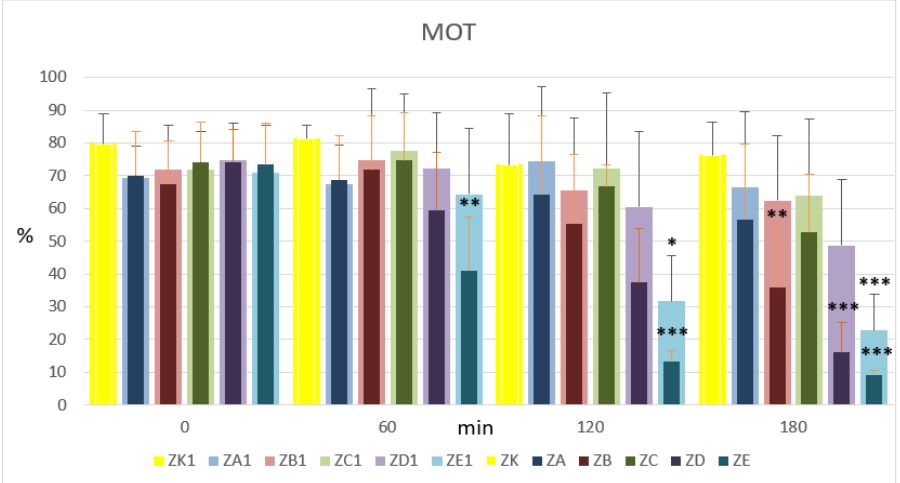

Figure 1 The effect of two forms of zinc with various doses of zinc on the total motility $(\%)$ of rabbit spermatozoa $(\mathrm{n}=8)$ in $0 \mathrm{~min}, 60 \mathrm{~min}, 120 \mathrm{~min}$ and $180 \mathrm{~min}$. Each bar represents the mean $( \pm \mathrm{SD})$. The level of significance was set at $* \mathrm{P}<0.05 ; * * \mathrm{P}<0.01 ; * * * \mathrm{P}<0.001$.

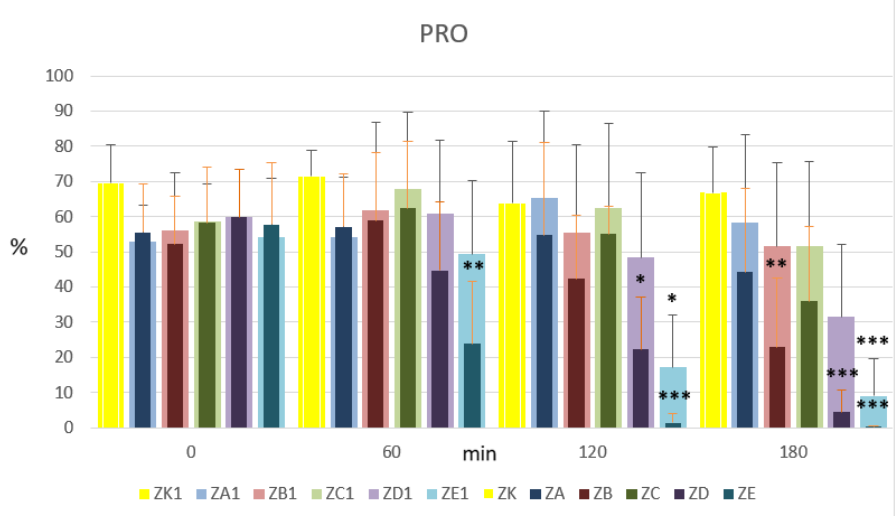

Figure 2 The effect of two forms of zinc with various doses of zinc on the progressive motility (\%) of rabbit spermatozoa $(\mathrm{n}=8)$ in $0 \mathrm{~min}, 60 \mathrm{~min}, 120 \mathrm{~min}$, $180 \mathrm{~min}$. Each bar represents the mean $( \pm \mathrm{SD})$. The level of significance was set at $* \mathrm{P}<0.05 ; * * \mathrm{P}<0.01 ; * * * \mathrm{P}<0.001$

Reflecting the trend of total motility, adverse effect of zinc was detected in progressive motility. Experimental sample ZE in times 120 and $180 \mathrm{~min}$ had progressive motility on $4.49 \pm 6.28 \%$ and $0.15 \pm 0.25 \%$. The lower progressive motility in comparison to control group was measured in each interval, only in sample ZA1 were observed very similar results as in control group after 120 minutes of incubation (Figure 2). Significant results were found in sample ZE after 60 minutes $(\mathrm{P}<0.01), 120$ and 180 minutes $(\mathrm{P}<0.001)$ of cultivation. Further significant results were monitored at interval $120 \mathrm{~min}$ in samples ZE1, ZD $(\mathrm{P}<0.05)$, at interval 180 minutes in samples $\mathrm{ZB}(\mathrm{P}<0.01), \mathrm{ZD}$ and $\mathrm{ZE} 1$ $(\mathrm{P}<0.001)$.

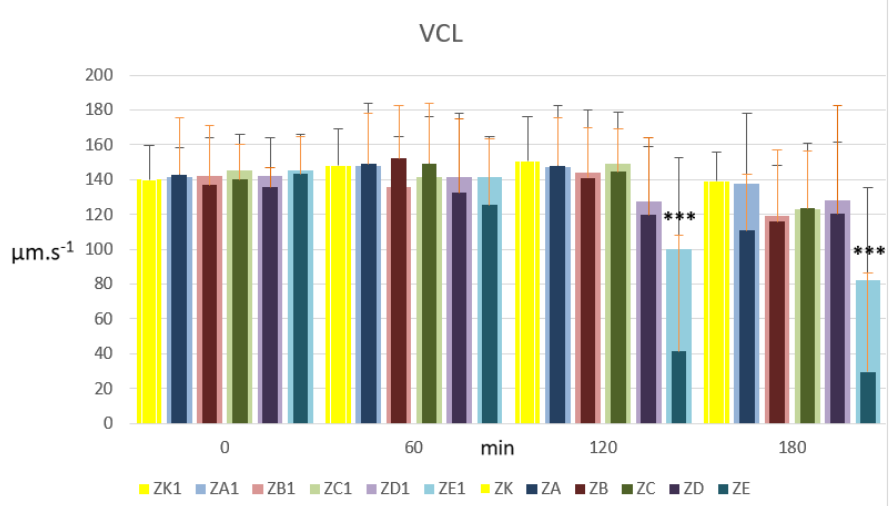

Figure 3 The effect of two forms of zinc with various doses of zinc on the velocity curved line $\left(\mu \mathrm{m} . \mathrm{s}^{-1}\right)$ of rabbit spermatozoa $(\mathrm{n}=8)$ in $0 \mathrm{~min}, 60 \mathrm{~min}$, $120 \mathrm{~min}, 180 \mathrm{~min}$. Each bar represents the mean $( \pm \mathrm{SD})$. The level of significance was set at $* \mathrm{P}<0.05 ; * * \mathrm{P}<0.01 ; * * * \mathrm{P}<0.001$.

Groups with addition of zinc in inceptive interval had approximately same values of velocity curved line as controls groups. Negative effect of zinc on spermatozoa velocity was represented especially by sample ZE (Figure 3). Evaluation of spermatozoa velocity curved line detected significant $(\mathrm{P}<0.001)$ decrease after 120 and 180 min of incubation in ZE. The lowest speed of rabbit spermatozoa 
was determined after 180 minutes of incubation in sample ZE with speed $29.57 \pm 57.00 \mu \mathrm{m} . \mathrm{s}^{-1}$ compared to control group with $138.96 \pm 16.87 \mu \mathrm{m} . \mathrm{s}^{-1}$.

MTT

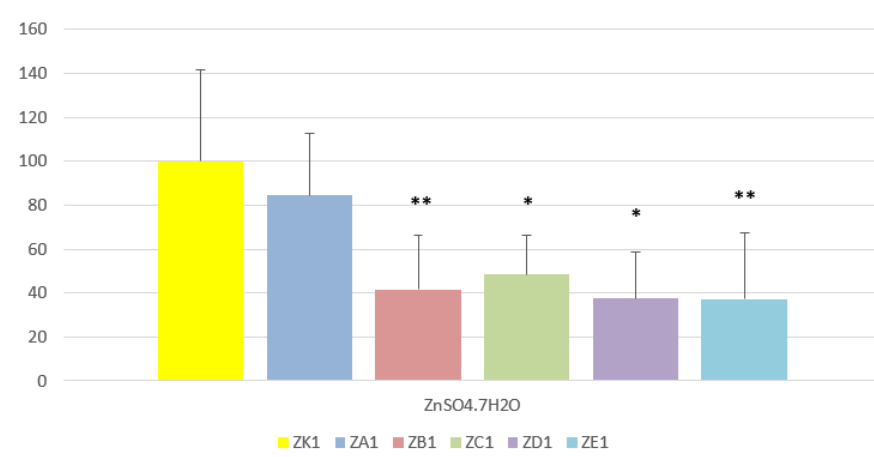

Figure 4 The effect of various doses of zinc $\left(\mathrm{ZnSO}^{4} .7 \mathrm{H}_{2} \mathrm{O}\right)$ on the viability $(\%)$ of rabbit spermatozoa $(n=8)$ assessed after 180 minutes of incubation. Each bar represents the mean $( \pm \mathrm{SD})$ of measured optical density and converted to percents The control was recalculated to $100 \%$. The level of significance was set at $* \mathrm{P}<0.05 ; * * \mathrm{P}<0.01 ; * * * \mathrm{P}<0.001$

MTT test, which monitors the production of succinate dehydrogenase, was used for determination of cell viability. According to the MMT assay, supplementation of zinc $\left(\mathrm{ZnSO}_{4} \cdot 7 \mathrm{H}_{2} \mathrm{O}\right)$ to fresh rabbit spermatozoa after 180 minutes of incubation had significantly negative effect on the cell viability in the experimental groups ZB1, ZE1 $(\mathrm{P}<0.01)$ and $\mathrm{ZC}$, ZD1 $(\mathrm{P}<0.05$; Figure 4).

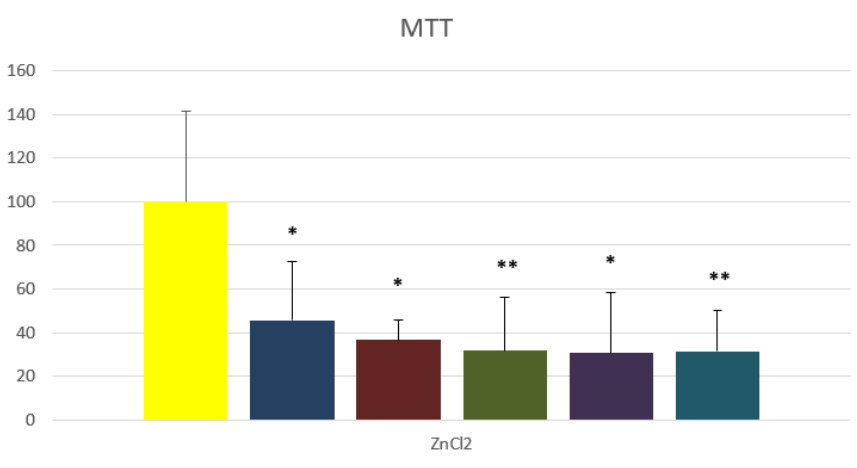

$Z K \backsim Z A \backsim Z B \backsim Z C \backsim Z D=Z E$

Figure 5 The effect of various doses of zinc $\left(\mathrm{ZnCl}_{2}\right)$ on the viability $(\%)$ of rabbit spermatozoa $(n=8)$ assessed after 180 minutes of incubation. Each bar represents the mean $( \pm \mathrm{SD})$ of measured optical density and converted to percents. The control was recalculated to $100 \%$. The level of significance was set at $* \mathrm{P}<0.05$; $* * \mathrm{P}<0.01 ; * * * \mathrm{P}<0.001$

Similar negative effect on cell viability was also recorded in the other form of zinc $\left(\mathrm{ZnCl}_{2}\right)$. Measurement showed results with significantly counteractive effect on viability in samples $\mathrm{ZA}, \mathrm{ZB}, \mathrm{ZD}(\mathrm{P}<0.05)$ and $\mathrm{ZC}, \mathrm{ZE}(\mathrm{P}<0.01$; Figure 5$)$.

The present study was design to study the effect of zinc supplementation to rabbit spermatozoa in vitro. Its presence is important in testes development (Merker and Günther, 1997), spermatogenesis (Yamaguchi et al., 2009) but some studies assert that influence of zinc on spermatozoa motility is still controversia (Gavella and Lipovac, 2009).

Few studies (Omu et al., 1998; Chia et al., 2000) show that a high concentration of zinc is connected with increased sperm motility. Results of other research paper (Colagar et al., 2009; Yamaguchi et al., 2009) suggest association between low zinc concentration and poor sperm quality. Also no significant correlation was indicated between level of seminal zinc and sperm motility (Lewis-Jones et al., 1996; Kotdawala et al., 2012). Association between lower spermatozoa motility and higher concentration of zinc in seminal plasma was observed in study focused on seminal plasma of older men (Henkel et al., 2006). Results of Narasimhaiah et al., (2018), who studied effect of various concentration of organic zinc supplemented to goat bucks feed showed significantly higher progressive motility compared to control group without feed supplemented with zinc.

Despite the fact that many studies evaluated seminal concentration of zinc and its effect on reproduction (Massányi et al., 2003, 2008; Krakowski et al., 2015; Kasperczyk, 2016), only few information are accessible for in vitro effect (Riffo et al., 1992; Gavella and Lipovac, 2009; Talevi et al., 2013). Gavella and
Lipovac (2009), who studied in vitro effect of zinc on oxidative changes in human semen observed that zinc participates in oxidative changes occurring afte ejaculation. Positive protective effect of in vitro treatment with zinc $\left(\mathrm{ZnCl}_{2}\right)$, daspartate and coenzyme q10 on human sperm motility, lipid peroxidation and DNA fragmentation were observed by Taveli et al. (2013). Riffo et al. (1992) confirmed effect of zinc $\left(\mathrm{ZnSO}_{4}\right)$ on human sperm motility, acrosome reaction as well as on capacitation. Wu et al. (2015) supplemented freshly ejaculated human spermatozoa with $\mathrm{ZnCl}_{2}$ along with $\mathrm{H}_{2} \mathrm{O}_{2}$. Added zinc was able to diminish $\mathrm{H}_{2} \mathrm{O}_{2}$ induced oxidative stress however zinc in semen samples without $\mathrm{H}_{2} \mathrm{O}_{2}$ caused decreased motility. In terms of motility, Barbato et al. (2017) confirmed positive effect of zinc in combination with D-aspartate and co-enzyme Q10 on spermatozoa with induced oxidative stress. Moreover also embryos, produced of oxidative stress affected spermatozoa and fresh oocytes, developed better in culture mediums treated with mentioned supplements.

The negative influence of zinc was detected also in carp spermatozoa. Chyb et al. (2000) in their study evaluated how zinc in different concentrations affects motility parameters, VCL (velocity curved line), VAP (average path velocity) and VSL (straight line velocity). Carp semen with added zinc in concentrations of 100 and 200 ppm showed significantly decreased motility parameters.

Results of several studies indicate that extracellular zinc truly effect sperm motility, whether effects positively or negatively depends on species and the dose (Stoltenberg, 1997; Yamaguchi et at., 2009).

\section{CONCLUSION}

The results of this study indicate that both forms of zinc used in present study have not beneficial effect on rabbit spermatozoa after incubation in different time periods. Supplemented zinc in form $\mathrm{ZnCl}_{2}$ to rabbit semen had higher negative impact on rabbit spermatozoa motility and viability parameters than zinc in form $\mathrm{ZnSO}^{4} .7 \mathrm{H}_{2} \mathrm{O}$. However, further studies with in vitro zinc supplementation may confirm the toxic effect of selected concentrations. Possibly, the addition of smaller concentrations of zinc might appear as beneficial.

Acknowledgments: The research was financially supported by the VEGA 1/0760/15, VEGA 1/0857/14, VEGA 1/05397/18, APVV-16-0289, APVV-150544, KEGA 010/SPU-4/2018 and AgroBioTech Research Centre built in accordance with the project Building „AgroBioTech" Research Centre ITMS 26220220180

\section{REFERENCES}

Barbato, V., Talevi, R., Braun, S., Merolla, A., Sudhakaran, S., Longobardi, S., \& Gualtieri, R. (2017). Supplementation of sperm media with zinc, D-aspartate and co-enzyme Q10 protects bull sperm against exogenous oxidative stress and improves their ability to support embryo development. Zygote, 25(2), 168-175. https://doi.org/10.1017/S0967199416000459

Bedwal, R. S., \& Bahuguna, A. (1994). Zinc, copper and selenium in reproduction. Experientia, 50(7), 626-640. https://doi.org/10.1007/bf01952862

Castellini, C. (2007). Reproductive activity and welfare of rabbit does. Italian Journal of Animal Science, 6(sup1), 743-747. https://doi.org/10.4081/ijas.2007.1s.743

Colagar, A. H., Marzony, E. T., \& Chaichi, M. J. (2009). Zinc levels in seminal plasma are associated with sperm quality in fertile and infertile men. Nutrition Research, 29(2), 82-88. https://doi.org/10.1016/j.nutres.2008.11.007

Duncan, M., Marini, A., Watters, R., Kopin, I., \& Markey, S. (1992). Zinc, a neurotoxin to cultured neurons, contaminates cycad flour prepared by traditional guamanian methods. The Journal of Neuroscience, 12(4), 1523-1537. https://doi.org/10.1523/jneurosci.12-04-01523.1992

Favier, A. E. (1992). The role of zinc in reproduction. Biological trace element research, 32(1-3), 363-382.

Fik, M. (2018). Possibilities of lecirelinum (GnRH) use in rabbits insemination Journal of Microbiology, Biotechnology \& Food Sciences, 7(5). https://doi.org/10.15414/jmbfs.2018.7.5.467-471

Fosmire, G. J. (1990). Zinc toxicity. The American Journal of Clinical Nutrition, 51(2), 225-227. https://doi.org/10.1093/ajen/51.2.225

Gavella, M., \& Lipovac, V. (2009). In vitro effect of zinc on oxidative changes in human semen. Andrologia, 30(6), 317-323. https://doi.org/10.1111/j.1439 0272.1998.tb01177.x

Halo Jr., M., Tirpák, F., Kováčik, A., Lípová, P., Greń, A., \& Massányi, P. (2018). Biochemical parameters of seminal plasma affect motility traits of stallion. The Journal of Microbiology, Biotechnology and Food Sciences, 7(5), 472-474. https://doi.org/10.15414/jmbfs.2018.7.5.472-474

Henkel, R., Maass, G., Schuppe, H. C., Jung, A., Schubert, J., \& Schill, W. B. (2006). Molecular Aspects of Declining Sperm Motility in Older Men. The Journal of Urology, 175(5), 1828. https://doi.org/10.1016/s0022-5347(06)00178 9

Chia, S. E., Ong, C. N., Chua, L. H., Ho, L. M., \& Tay, S. K. (2000). Comparison of zinc concentrations in blood and seminal plasma and the various sperm parameters between fertile and infertile men. Journal of andrology, 21(1), 53-57. https://doi.org/10.1002/j.1939-4640.2000.tb03275.x 
Chyb, J., Kime, D. E., Mikolajczyk, T., Szczerbik, P., \& Epler, P. (2000). The influence of zinc on sperm motility of common carp-a computer assisted studies. Archiwum Rybactwa Polskiego, 8(1), 5-14

Jambor, T., Tvrdá, E., Tušimová, E., Kováčik, A., Bistáková, J., Forgács, Z., \& Lukáč, N. (2017). In vitro effect of 4-nonylphenol on human chorionic gonadotropin (hCG) stimulated hormone secretion, cell viability and reactive oxygen species generation in mice Leydig cells. Environmental Pollution, 222, 219-225. https://doi.org/10.1016/j.envpol.2016.12.053

Kasperczyk, A., Dobrakowski, M., Czuba, Z., Kapka-Skrzypczak, L., \& Kasperczyk, S. (2015). Environmental exposure to zinc and copper influences sperm quality in fertile males. Annals of Agricultural and Environmental Medicine, 23(1), 138-143. https://doi.org/10.5604/12321966.1196869

Kendall, N. ., McMullen, S., Green, A., \& Rodway, R. . (2000). The effect of a zinc, cobalt and selenium soluble glass bolus on trace element status and semen quality of ram lambs. Animal Reproduction Science, 62(4), 277-283. https://doi.org/10.1016/s0378-4320(00)00120-2

Kerns, K., Zigo, M., Drobnis, E. Z., Sutovsky, M., \& Sutovsky, P. (2018). Zinc ion flux during mammalian sperm capacitation. Nature communications, 9(1), 2061. https://doi.org/10.1038/s41467-018-04523-y

Kime, D. ., Ebrahimi, M., Nysten, K., Roelants, I., Rurangwa, E., Moore, H. D. ., \& Ollevier, F. (1996). Use of computer assisted sperm analysis (CASA) for monitoring the effects of pollution on sperm quality of fish; application to the effects of heavy metals. Aquatic Toxicology, 36(3-4), 223-237. https://doi.org/10.1016/s0166-445x(96)00806-5

Krakowski, L., Wachocka, A., Brodzki, P., Wrona, Z., Piech, T., Wawron, W., \& Chałabis-Mazurek, A. (2015). Sperm quality and selected biochemical parameters of seminal fluid in dogs with benign prostatic hyperplasia. Animal Reproduction Science, 160, 120-125. https://doi.org/10.1016/j.anireprosci.2015.07.014

Kotdawala, A. P., Kumar, S., Salian, S. R., Thankachan, P., Govindraj, K. Kumar, P., ... \& Adiga, S. K. (2012). Addition of zinc to human ejaculate prior to cryopreservation prevents freeze-thaw-induced DNA damage and preserves sperm function. Journal of assisted reproduction and genetics, 29(12), $1447-$ 1453. https://doi.org/10.1007/s10815-012-9894-8

Lewis-Jones, D. I., Aird, I. A., Biljan, M. M., \& Kingsland, C. R. (1996). Andrology: Effects of sperm activity on zinc and fructose concentrations in seminal plasma. Human reproduction, 11(11), 2465-2467. https://doi.org/10.1093/oxfordjournals.humrep.a019138

Lukac, N., Bardos, L., Stawarz, R., Roychoudhury, S., Makarevich, A. V., Chrenek, P., ... \& Massanyi, P. (2011). In vitro effect of nickel on bovine spermatozoa motility and annexin V-labeled membrane changes. Journal of Applied Toxicology, 31(2), 144-149. https://doi.org/10.1002/jat.1574

Massanyi, P., Trandzik, J., Nad, P., Toman, R., Skalicka, M., \& Korenekova, B. (2003). Seminal concentrations of trace elements in various animals and their correlations. Asian journal of andrology, 5(2), 101-104.

Massanyi, P., Weis, J., Lukac, N., Trandzik, J., \& Bystricka, J. (2008). Cadmium, zinc, copper, sodium and potassium concentrations in rooster and turkey semen and their correlation. Journal of Environmental Science and Health, Part A, 43(5), 563-565. https://doi.org/10.1080/10934520701796655

Merker, H.J., Günther, T. (1997) Testis damage induced by zinc deficiency in rat Journal of Trace Elements in Medicine and Biology, 11(1), 19-22. https://doi.org/10.1016/S0946-672X(97)80004-1

Narasimhaiah, M., Arunachalam, A., Sellappan, S., Mayasula, V. K., Guvvala, P. R., Ghosh, S. K., ... \& Kumar, H. (2018). Organic zinc and copper supplementation on antioxidant protective mechanism and their correlation with sperm functional characteristics in goats. Reproduction in Domestic Animals, 53(3), 644-654. https://doi.org/10.1111/rda.13154

Nenkova, G., Petrov, L., \& Alexandrova, A. (2017). Role of Trace Elements for Oxidative Status and Quality of Human Sperm. Balkan Medical Journal, 34(4), 343. https://doi.org/10.4274/balkanmedj.2016.0147

Omu, A. E., Dashti, H., \& Al-Othman, S. (1998). Treatment of asthenozoospermia with zinc sulphate: andrological, immunological and obstetric outcome. European Journal of Obstetrics and Gynecology and Reproductive Biology, 79(2), 179-184. https://doi.org/10.1016/s0301-2115(97)00262-5

Riffo, M., Leiva, S. \& Astudillo, J. (1992). Effect of zinc on human sperm motility and the acrosome reaction. International Journal of Andrology, 15, 229 237. https://doi.org/10.1111/j.1365-2605.1992.tb01343.x

Slanina, T., Petrovičová, L., Miškeje, M., Kňižat, L., Mirda, J., Lukáč, N., ... Massányi, P. (2014). The effect of diluent, temperature and age on turkey spermatozoa motility in vitro. Journal of Applied Animal Research, 43(2), 131136. https://doi.org/10.1080/09712119.2014.928627

Stoltenberg, M. (1997). Autometallographic demonstration of zinc ions in rat sperm cells. Molecular Human Reproduction, 3(9), 763-767. https://doi.org/10.1093/molehr/3.9.763

Talevi, R., Barbato, V., Fiorentino, I., Braun, S., Longobardi, S., \& Gualtieri, R. (2013). Protective effects of in vitro treatment with zinc, d-aspartate and coenzyme q10 on human sperm motility, lipid peroxidation and DNA fragmentation. Reproductive Biology and Endocrinology, 11(1), 81 https://doi.org/10.1186/1477-7827-11-81
Tirpák, F., Slanina, T., Kováčik, A., Ondruška, L., Massányi Jr., P., Halo Jr., M., Massányi, P. (2017). Low taurine concentrations possitively affect rabbit spermatozoa properties in later time intervals. Journal of Microbiology, $\begin{array}{lllll}\text { Biotechnology and Food Sciences, } 7 & \text { (2), 128-131. }\end{array}$ https://doi.org/10.15414/jmbfs.2017.7.2.128-131

Valko, M., Morris, H., \& Cronin, M. (2005). Metals, Toxicity and Oxidative Stress. Current Medicinal Chemistry, 12(10), 1161-1208. https://doi.org/10.2174/0929867053764635

Wu, J., Wu, S., Xie, Y., Wang, Z., Wu, R., Cai, J., ... \& You, L. (2015). Zinc protects sperm from being damaged by reactive oxygen species in assisted reproduction techniques. Reproductive biomedicine online, 30(4), 334-339. https://doi.org/10.1016/j.rbmo.2014.12.008

Yamaguchi, S., Miura, C., Kikuchi, K., Celino, F. T., Agusa, T., Tanabe, S., \& Miura, T. (2009). Zinc is an essential trace element for spermatogenesis. Proceedings of the National Academy of Sciences, 106(26), 10859-10864 https://doi.org/10.1073/pnas.0900602106 